MARCIN MARON

Faculty of Arts

Maria Curie-Skłodowska University, Lublin
Images

vol. XXVII/no. 36

Poznań 2020

ISSN 1731-45OX

\title{
Functions of screen space in shots by Mieczysław Jahoda in the example of his first feature films: Zimowy zmierzch and Pętla
}

\begin{abstract}
Maron Marcin, Functions of screen space in shots by Mieczysław Jahoda in the example of his first feature films: Zimowy zmierzch and Pętla. "Images" vol. XXVII, no. 36. Poznań 2020. Adam Mickiewicz University Press. Pp. 129-142. ISSN 1731-450X. DOI 10.14746/i.2020.36.08.

The text is devoted to discussing the formation methods and the functions of screen space in shots by Mieczysław Jahoda in the films Zimowy zmierzch (directed by S. Lenartowicz) and Pętla (directed by W.J. Has). Mieczysław Jahoda is presented as one of the main initiators of stylistic changes in the films of Polish School in the mid 1950s. The analysis concerns the camera means applied by Jahoda in order to obtain screen effects: light, frame composition, photographic optics and perspective transformation. The film shots by Mieczysław Jahoda are characterized by an exceptional ability to evoke mental space, emotions, memory and imagination via the shapes of screen space. Their feature is a special esthetization aimed at creating the atmosphere of films, as well as symbolic and cultural references.
\end{abstract}

KEYwORDS: Mieczysław Jahoda, art of cinematography, film space, Stanisław Lenartowicz, Wojciech J. Has, Polish Film School

Mieczysław Jahoda (b. 1924) is a member of the groups of directors of photography who, in the second half of the 1950s, created the Polish School and contributed to the significant improvement of the role of film image.[1] In total M. Jahoda's work as a cinematographer lasted more than four decades - until the end of 1980s. Over almost forty years, while Polish cinematography was created and developing, Jahoda cooperated with the group of leading film directors, including Stanisław Lenartowicz, Wojciech Jerzy Has, Aleksander Ford, Jan Rybkowski, Andrzej Wajda, Andrzej Żuławski, Tadeusz Konwicki, Jerzy Gruza and Stanisław Jędryka. He was the co-author of their best films. Some of them became a testimony to the grandness of the Polish cinema.

Mieczysław Jahoda's feature film debut as the director of photography was Zimowy zmierzch directed by Stanisław Lenartowicz in 1956. Before that happened, however, Jahoda had ten years of apprenticeship as a film maker as a student of film in Krakow (1945-1946), a student of the Film School in Łódź (1949-1953), a camera assistant on film sets and finally, as a camera operator (1951-1956). In this period Jahoda met the people who decided on the form of Polish cinema, a Jerzy Ka-

[1] M. Maron, Mieczysław Jahoda. Fenomeny światła, Łódź 2019. 
walerowicz and Jan Rybkowski. One of the most important ones was Stanisław Wohl, who then had the least practical experience among Polish cinematographers and was a significant influence on the training system for the Film School. Wohl emphasized that Polish film education, since it began after World War II, had been formed by the assumption

[...] that the director of photography was responsible for the film image as a whole, for lightening, arrangement, shortly: for the whole scope of staging. [...] The director of photography's first task is to learn the art of telling stories through images [...]. That is the task of staging. [...] The place where the camera is placed, lighting of the plan, selection of lenses (the interpret the space in a specific way) - all that is included in the scope of the cinematographers tasks and determines the artistic rank of that profession[2]

- Wohl explained. Mieczysław Jahoda understood these assumptions and soon applied them in practice, with excellent results.

He did have a piece of luck with that; the departure from socialist realism in the Polish culture of the late 1950 meant a chance for some young filmmakers. Jahoda, in his early thirties at that time, was very well prepared for it. This is proven by his feature film debut. In fact, this was the first Polish movie which was totally free from social realism. It was also one of the first films where the new image stylistics played the main role. This moment was the beginning of a long period in which Mieczysław Jahoda worked very hard as an author of film shots.

Mieczysław Jahoda's art of cinematography from the very beginning was connected with the awareness that the director of photography was the author of the visual shape of the film, made concrete in a photographic image.[3] In the early period of Jahoda's artistic work, this was related to his ability to exploit the possibilities of black and white film stock. He quickly became a virtuoso of black and white film. In the films he made with Lenartowicz (Zimowy zmierzch, Spotkania) and Has (Pętla, 1957; Pożegnania, 1958) there are many references to noble patterns of artistic cinema, but first of all they constitute the cameraman's own expression of his creative ideas. They are very successful attempts at creating so-called atmosphere films. The atmosphere was treated as a means of expression creating "the sum of moods coming from the surroundings" and "the spiritual climate of the living people." [4] An atmosphere film is a film in which the image is especially intense, giving new faces to visual things. Creating the atmosphere involved the appropriate combination and cooperation of: light, film movement, composition of the image and points of view of the camera, that is, a skilful arrangement of screen space.[5] Jahoda wrote: "The film

[2] S. Wohl, Operator? To filar polskiego kina. Nasza rozmowa z prof. Stanisławem Wohlem, rozmawiała

B. Mruklik, "Kino" 1972, no. 7, p. 34. [3] M. Jahoda, Styl plastyczny obrazu filmowego a indywidualność twórcy-operatora, praca magisterska (maszynopis), Archiwum PWSFTviT, Łódź 1953, p. 1.
[4] Ibidem, p. 13.

[5] My understanding of "screen space" concerns the coefficients creating the "inter-frame space", which is what the cameraman (or director of photography) can see in the camera frame and how they transform thatimage using operator measures into the screen 
achieves real atmosphere when the elements of contents, scenery and the actors' performance are expressed in the same tone." [6]

The principal factor determining the atmosphere and shapes of space in the first films made by Mieczysław Jahoda is lighting. Zimowy zmierzch and Pętla were made in an atelier. The key role besides that of the actors - is played by the production design, the space and props. The exquisite visual and dramatic form of the film space is created mainly by the light. "Light is the factor that in the greatest degree allows for talking about the style of a given camera operator" [7] - Jahoda claimed.

According to Mieczysław Jahoda light can be used in a double sense: "rationally", corresponding to real lightening conditions, or "emotionally", "to turn the viewers' attention to the places of the image, which are important because of the mood." [8] In Zimowy zmierzch and Pętla the director of photography created the light that can be defined as artificial, "anti-solar", "emotional" light. In these films, lighting creates first of all a visual symbiosis of the shapes of people and elements of the space, as well as the emotional mood of the scenes. Jahoda applied basic lighting schemes, typical of classic cinema-key light, giving the chiaroscuro modeling of the characters' faces or silhouettes, back (counter) light, creating clear outlines, the background light, directed at objects and walls, giving a spatial character to the image. He could also finely enrich and "spice" these schemes. He lit up the actors' faces precisely and beautifully, emphasizing the dramatic expression of their performance. The effect of such procedures was a very sensual chiaroscuro modeling- the game of values, textures and contrasts suggesting and releasing the visual tensions and the viewers; emotions with them.

Zimowy zmierzch is a chamber psychological drama taking place in a small village on the Eastern Border of Poland. The protagonists are part of the local community. The authors of the film focused mainly on the protagonists' emotions. That was a novum in Polish cinema after the period when social realist schemes were in force. The mood of mystery and loneliness is co-created by the scenery: winter plain airs seen at different times of the day (usually at night and at dusk), as well as tiny house interiors, full of different objects and devices. Religious symbols also appear there.

Mieczysław Jahoda knew that the principal determinants of visual style in artistic film were: "shot, lighting, frame composition,

effect. These measures co-create the visual form of the image: light, camera movement, lenses and compositional tricks. Like Rudolf Arnheim, I pay special attention to the film's way of creating an illusion of a three-dimensional space and the possibility of transforming the effects of depth through perspective deformations. In the theory of film, screen space can be understood in many different ways, depending on methodology and is usually defined as different from the space of a film frame. Cf. e.g. M. Hendrykowski, Ekran i kadr, "Przestrzenie Teorii" 2002, no. 1, p. 137-148.

[6] M. Jahoda, Styl plastyczny..., p. 13.

[7] Ibidem, p. 6.

[8] Ibidem. 
camera movement, angle of view, detail accents, optics (lenses) and creating the new reality." [9] All these camera art elements were applied in Zimowy zmierzch in an original way. The basic methods were creating the staging that underwent strong visual transformations in the film frame, as well as symbolization.

The lighting used by Mieczysław Jahoda in Zimowy zmierzch meets three basic functions. Firstly, light made it possible to realistically describe the spaces in which the film is set (a railway station, small town space, interiors of houses). Secondly, the artificial light co-creates the intimate atmosphere of the film space. It penetrates the material world and creates unrealistic visual effects. Thirdly, the lights seen in the frame give symbolic features to film spaces (e.g. lights lit in a church).

In Zimowy zmierzch we can notice the principle of creating reinforced lighting contrasts, as well as the strong sketch of figures and spaces by means of strong directional light falling from behind and from the side (in night time photography). The light clearly interacts with the matter - snow, falling and lying on the ground (revealing its texture), clothes and the wooden surfaces of the walls of buildings. The light builds the depth of frames and creates dynamic compositions based on the sharp border between the lit parts of the image, and those covered in shadow. This is the light that livens up the space, determines its character and creates the mood.

The second basic factor that creates the visual shapes of film images and atmosphere of the space, besides light, is the frame composition in Zimowy zmierzch.

It has to be remembered that film composition is connected with projecting and transforming the three-dimensional space and contrary to the painting composition -with the elements of movement contained in that space, or resulting from camera movement. The film composition is never utterly static and remains open to changes, as well as to other compositions in shots coming one after another. It is also important that

$[\ldots]$ the cameraman $[\ldots]$ must comprehend the composition in the area of the whole shot, sequence and scene, i.e. the composition of the film's image is determined by the composition of the whole film, its logic and idea [...] composition, just like light, is exclusively the role of the cameraman, shows their style and originality. The significance of composition is connected with the matter of the so-called "depth structure of the scene" [10]

- Mieczysław Jahoda said.

In Zimowy zmierzch the depth of space in the frame is created first of all to achieve the "centripetal", introspective effect. The director of photography achieved the fantastic effect of visual connection between characters, the space and its details (props), as well as the film movement. This plays a double role: firstly, it inscribes the protagonists into the small town milieu and the space of residential interiors, 
where the film takes place, and secondly - it co-creates the emotional atmosphere of the film and its symbolic meanings. The complexity of the composition is co-formed by numerous props and chiaroscuro, and the depth of the frame is magnified by using mirrors and the reflections in them (il. 1-2).
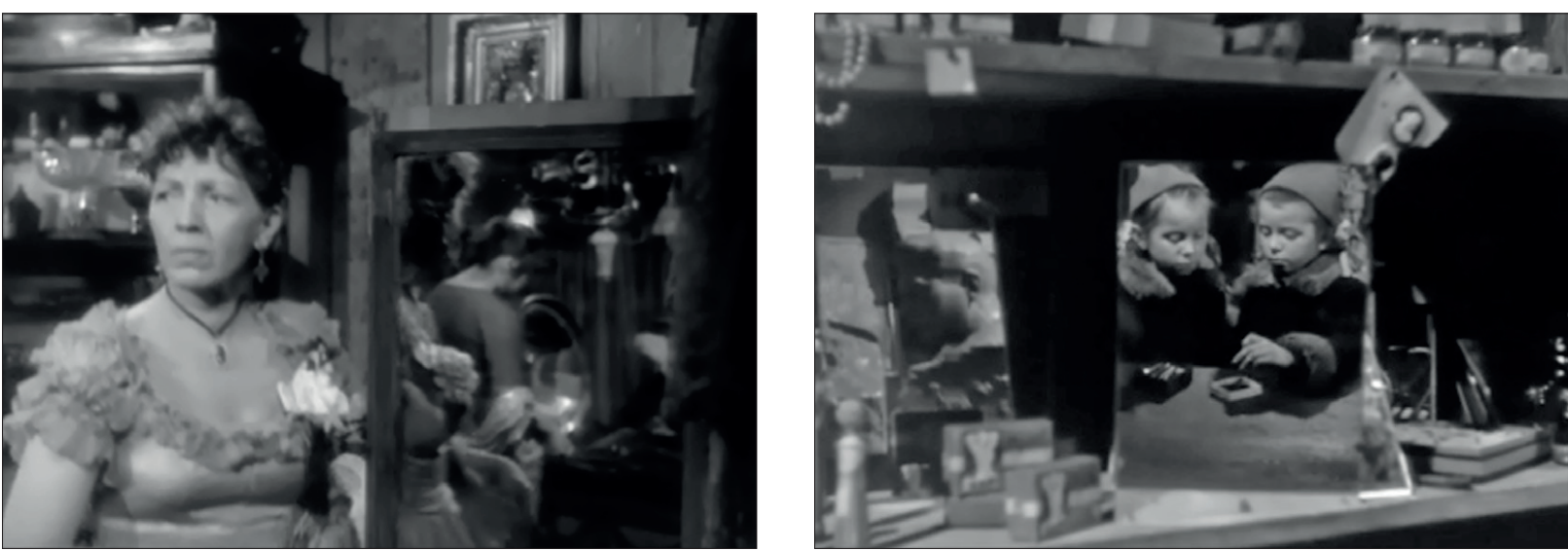

In Zimowy zmierzch, the protagonists' experiences and emotions are especially important. That is why their portraits (close-ups) are Il. 1-2. Zimowy zmierzch, dir. S. Lenartowicz significant. The actor's face becomes the centre of the film's atmosphere. The images emphasize loneliness in spite of the presence of people the protagonists are close to (il. 3-6). In the film, due to the skillful creation

Il. 3-6. Zimowy zmierzch, dir. S. Lenartowicz
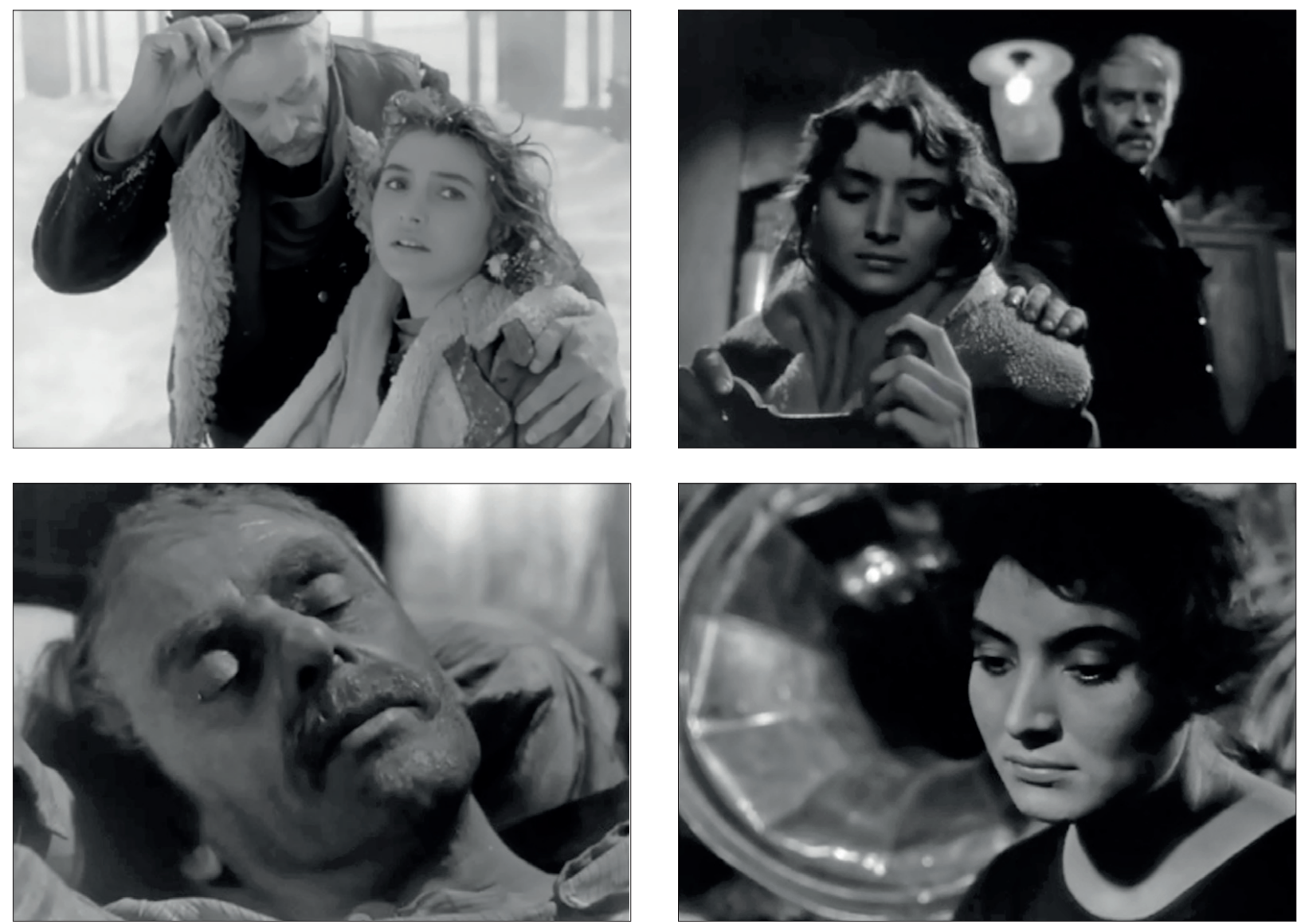
of shot compositions; additionally, the broader, community aspect of connections between people was presented. That is why in Zimowy $z$ mierzch group compositions are really significant. They show the community (family, small town community) in a state of disintegration or integration. This happens e.g. in the scenes taking place in Rumsza's house, in an inn or during church celebrations (il. 7-8).
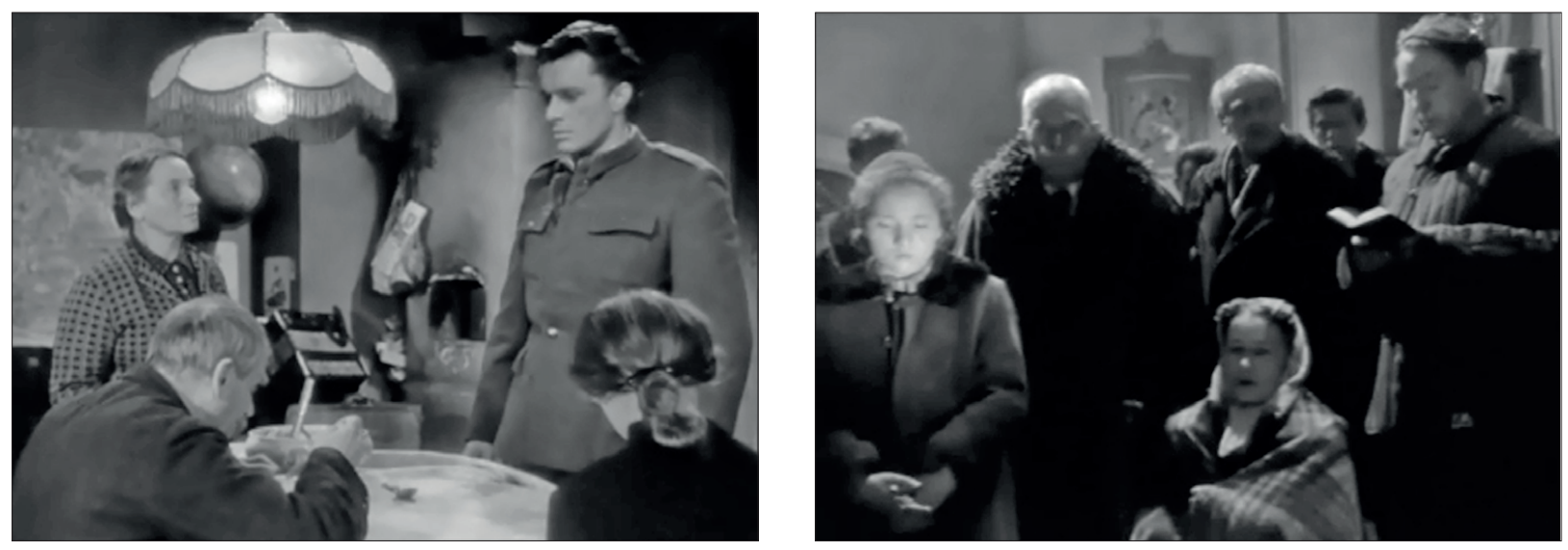

Il. 7-8. Zimowy zmierzch, dir. S. Lenartowicz

Il. 9-12. Zimowy zmierzch, dir. S. Lenartowicz
What plays a special role in Zimowy zmierzch is the image composition, where the symbolism of objects is important. These objects occur as elements of places and and events in which the protagonists participate (e.g. the shows of carol singers, liturgical celebrations and props of residential space, il. 9-12). In spite of that they become a signal of the invisible
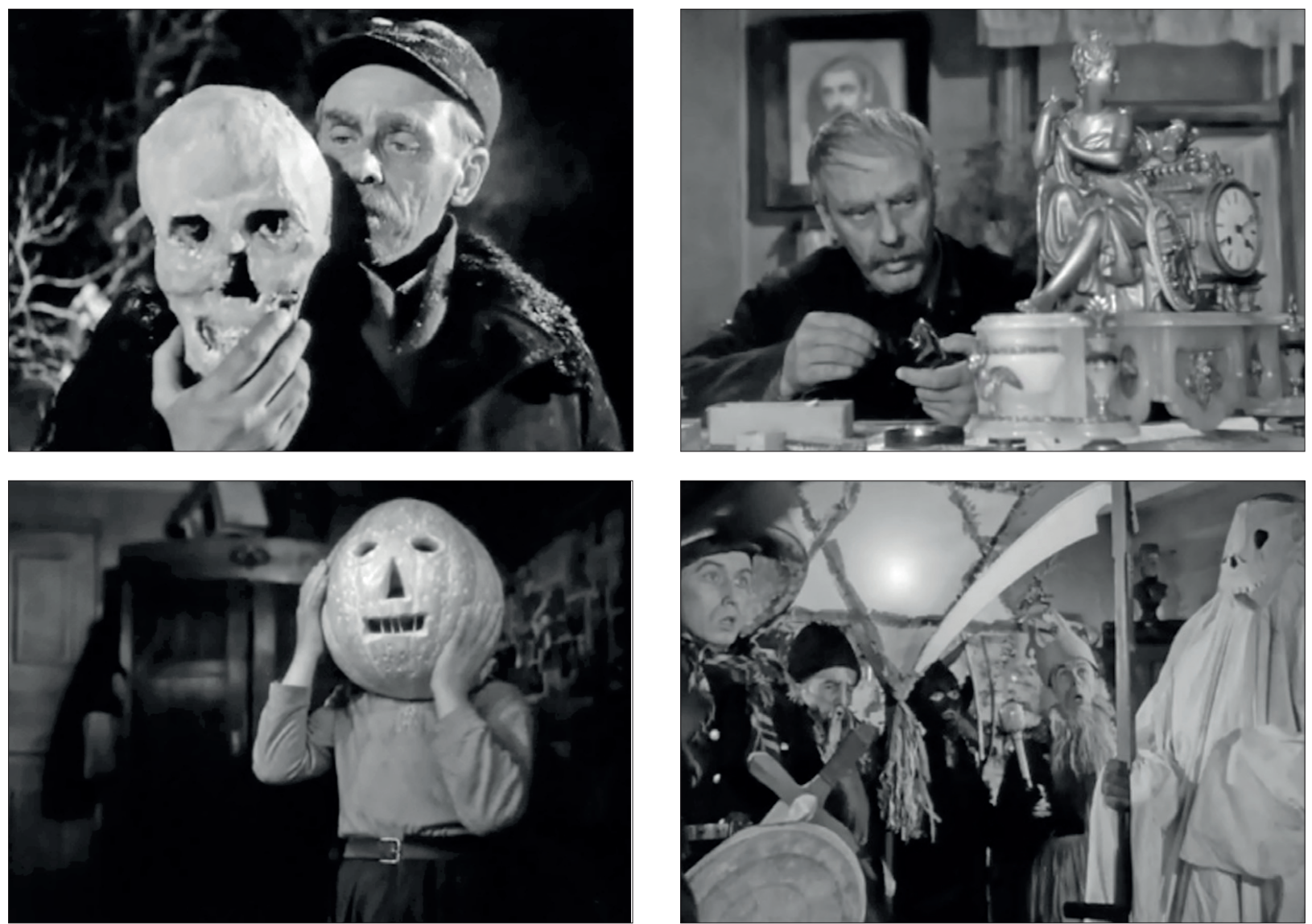
sphere. Their symbolic meanings concern in a state of disintegration or integration. This happens evoke the possibility of spiritual transformation and connection with the sphere of transcendence.

That second role is played especially by numerous compositions emphasizing religious symbolism: motifs of the cross and Christ (il. 13-14). The film image may be deciphered in connection with Christian understanding of the image, suggestingthat "between the sphere cognizable by reason and the sphere that can be perceived by senses - a certain indirect ontological and ontophanic layer, an imaginary world, where certain events take place that can be seen by the eyes of the mind." [11]

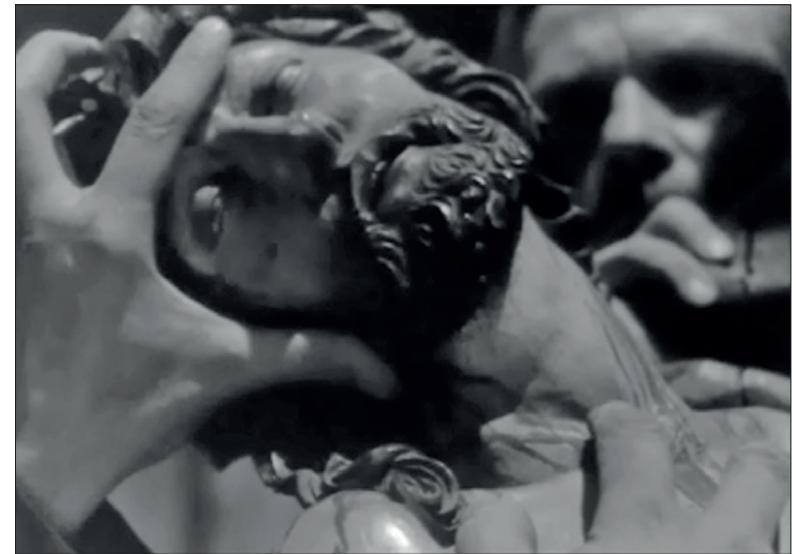

The characteristic compositional dynamics and depth of the space in the frame was achieved by Mieczysław Jahoda, thanks to the application of lower and upper points of view of the camera (il. 15-16) and with the use of broad-angled lenses (short focal length lenses), as well as the skilful application of camera movement and the movable objects in the frame.

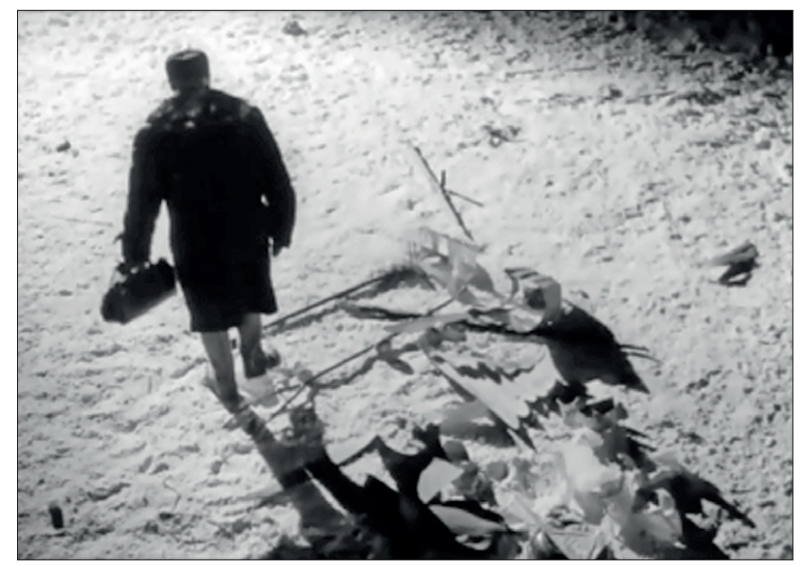

In Zimowy zmierzch the scenes of the main protagonist's - an old railway worker, Rumsza - visions and dreams are distinctive. They

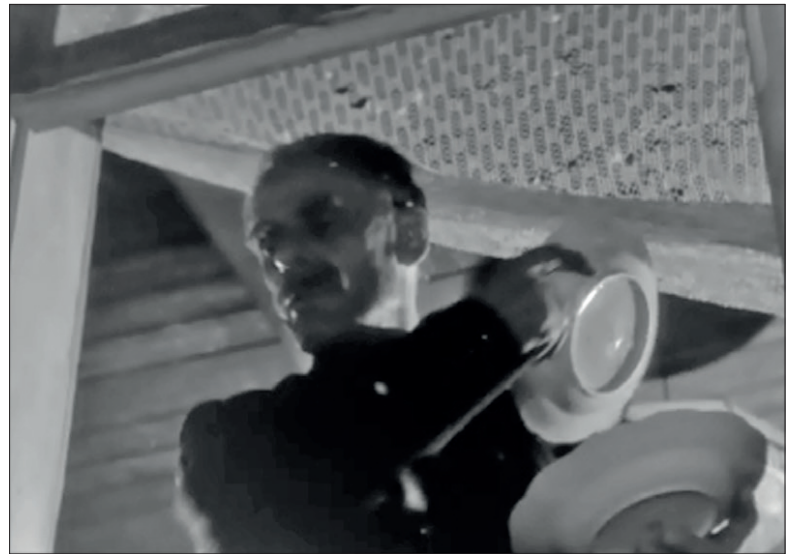

Il. 15-16. Zimowy zmierzch, dir. S. Lenartowicz

[11] J.-J. Wunenburger, Filozofia obrazów, tłum.

T. Stóżyński, Gdańsk 2011, p. 133. 
refer to the film space and the visual motifs known from avant garde films. The stylistics of oneiric sequences freely refers to various avant garde motifs: from surrealist (use of props and mannequins) and expressionist (painted scenery), to French (deformations of image) and Russian avant garde (a frame with victims beaten up by the police on the stairs; il. 17-20).
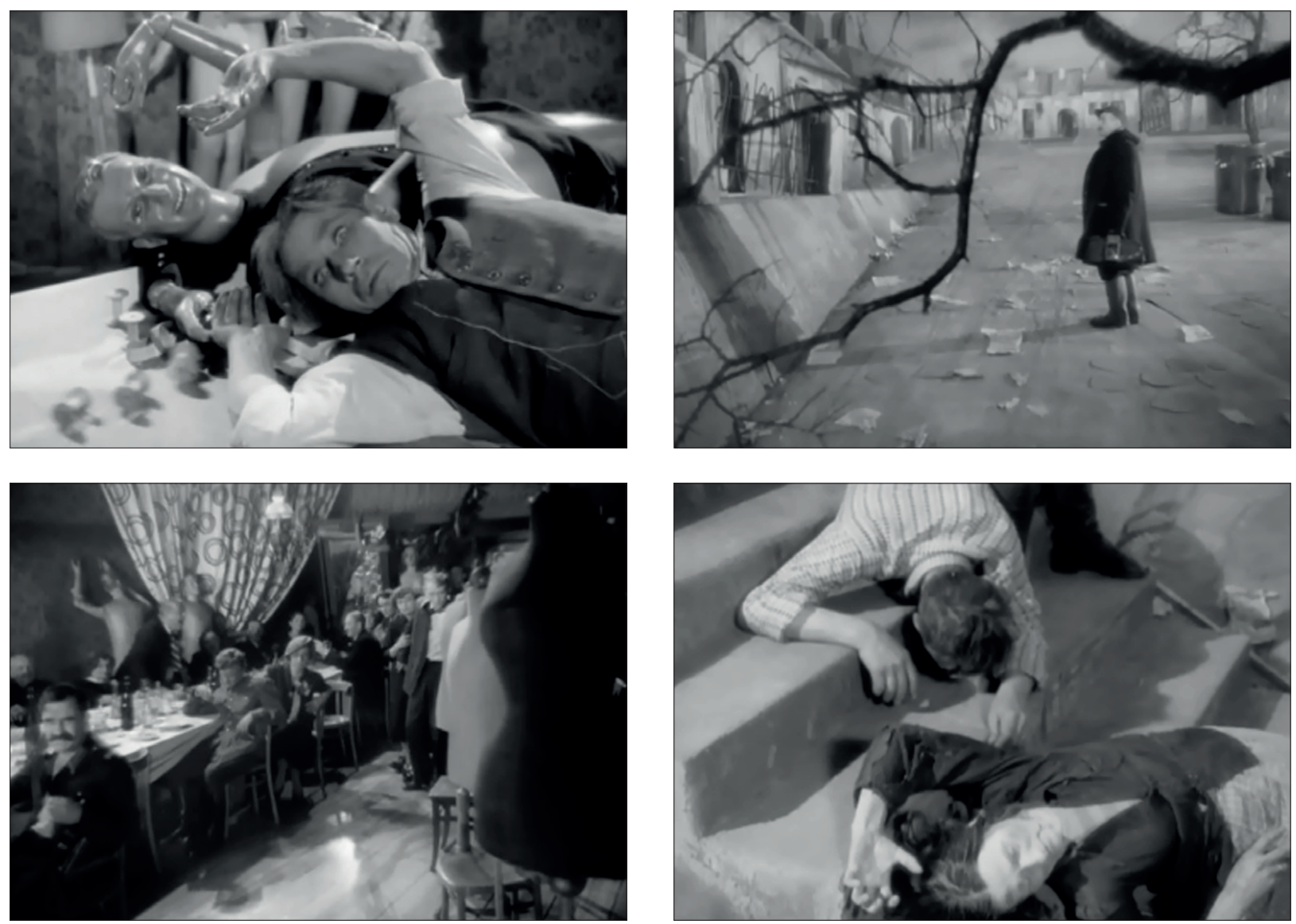

Il. 17-20. Zimowy zmierzch, dir. S. Lenartowicz
In the film Pętla (1957), the feature debut of Wojciech J. Has and the third film with Mieczysław Jahoda as the director of photography we can notice the development of methods applied by the cameraman in the debut. Petla is a film about twenty-four hours in the life of an alcoholic. The image of a man stigmatized with a weakness for alcohol enabled the film makers to describe the states of a consciousness under constant stress, under pressure from anxiety and memory.

Pętla is a film where the mood of the shots created by Mieczysław Jahoda is of special importance. Preparations for the film were based on close cooperation between the director, cameraman and the stage designer. The role of scenery in creating the film shots was especially significant. It was designed by Roman Wołyniec, for whom it was his debut as a production designer. As Konrad Eberhardt rightly remarked: "the function of scenery and decoration is different in Pętla 
than in a range of films we know, its connection with the protagonist is much closer, more intimate and it constitutes something like extension of his consciousness, or even sub-consciousness." [12]

Pętla can be defined as an atelier film,[13] though some of the shots were taken in urban plain air. It is set in four interiors built in an atelier (these are: Kuba's flat with adjacent staircase, a militia station, a cafe, and the inn "Pod Orłem"), as well as in the streets and alleys of the towns. The time of the film covers 24 hours - from 8 a.m. to 8 a.m. on the next day, when the protagonist commits suicide.

When creating atelier interiors the main rule was making them on the plan of deformed trapezes and joining them with a broad passage (doors broader than usual) and placing one of them on a platform (the effect of a stage; il. 21-22). Ceilings are responsible for enclosing the space, and the visual expression is strengthened by irregular walls surfaces (wainscots, pilasters), textures and a great number of props functional and also added in accordance with the ideas of film makers (in. a. a large, stuffed bird over the bar in the inn).

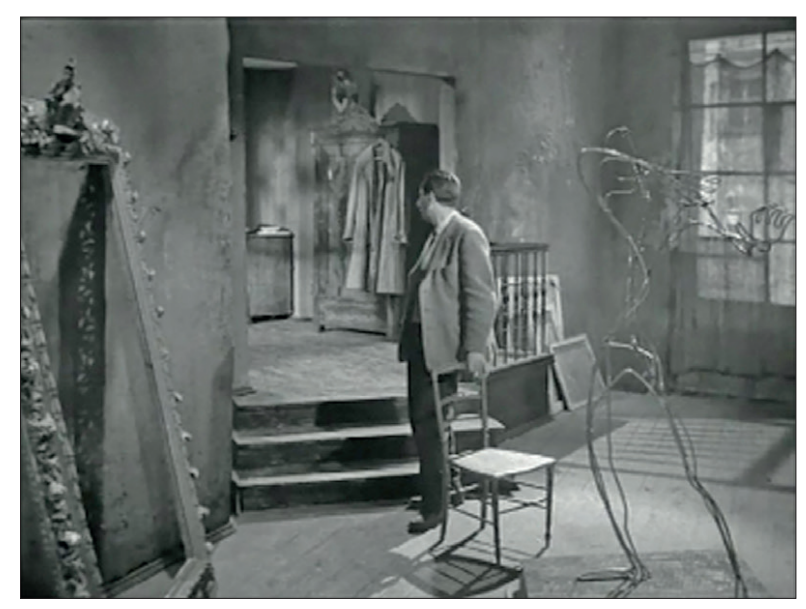

A disturbing visual form is also shown in urban spaces. They are streets with high tenement houses with curved and closed perspective, yards surrounded by outhouses, gates and a small tunnel. The urban space is characterized by details, such as numerous windows, sharp wall textures, and transport lines and rails, as well as elements added by the film makers: large props, such as carousel, hearse, coffins, aluminum cans, boards lying across the dug-through street etc. (il. 23-24).

The scenery space presented in this way could be transformed with the use of the operator's methods: frame composition, chiaroscuro, the camera point of view, and movement. The results of all that were rich and visually refined film compositions.

[12] K. Eberhardt, Wojciech Has, Warszawa 1967, p. 11. [13] According to the stage designer Anatol Radzinowicz, an atelier film is a film that takes place outdoors only in 20-3o per cent - cf. A. Radzinowicz, Scenografia filmowa, Łódź 1958, p. 46. 

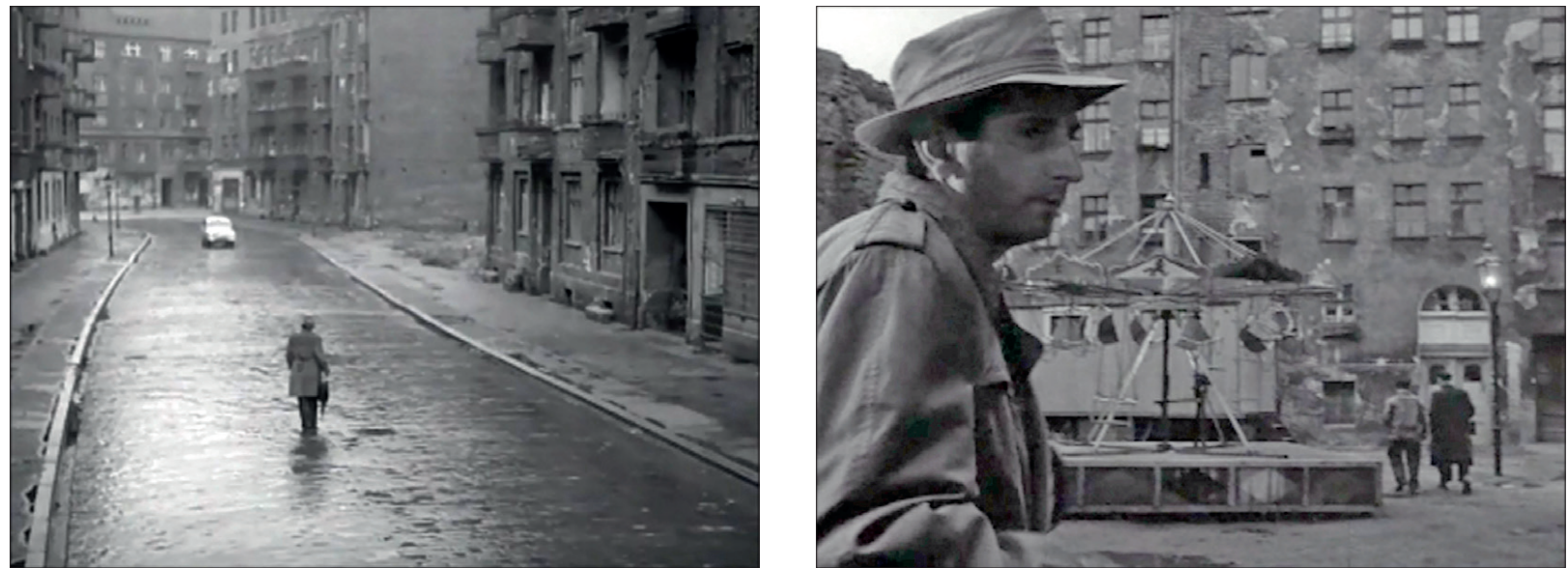

Il. 23-24. Pętla, dir. W.J. Has

Pętla was made as a black and white film, in a classical format $(1: 1,37)$. Mieczysław Jahoda managed to fully exploit the possibilities given by black and white film, first of all with - the contrast. Jahoda used the directed light falling - even during a single shot - from different directions at the same time, using lamps of different power and different width of the light stream. Sharp chiaroscuro outlines of the actors' faces, objects and elements of space predominates in the film (il. 25-26).
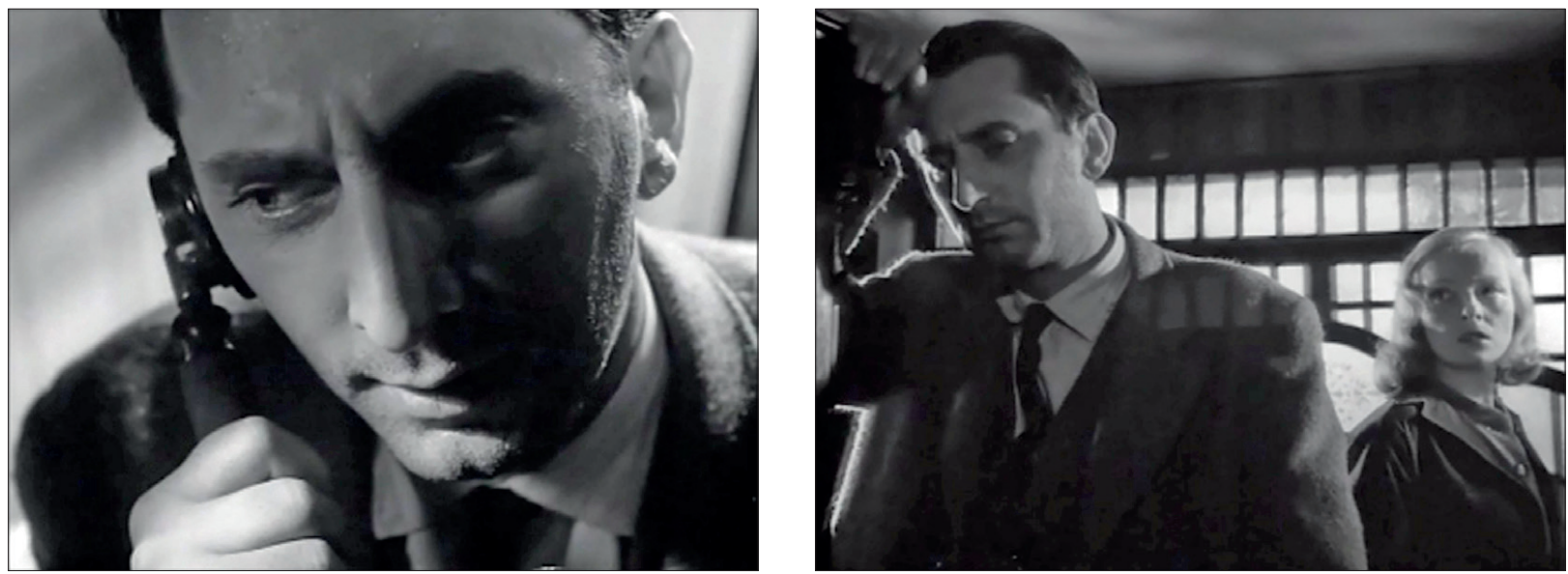

Il. 25-26. Pętla, dir. W.J. Has

In broader plans, in turn, sharp, upper light, outlining characters and objects (throwing shadows on the floor), creates complex systems of light and shadow, thus reinforcing the disturbing atmosphere of the film. In the street scenes, at night, the rear light lies in light slides on the walls of buildings and pavements, and car lights beaming from upper and side directions throw narrow streaks of light through which figures pass. That creates the depth of space, but also complicates the compositional arrangement of the frame (il. 27-28).

In extreme cases, this gives the impression of the main protagonist melting into the still space surrounding them, making them an object in a sense (streets at night, staircase in the scene when drunken Kuba returns home; il. 29-30). In the final shots of the film high contrast and interchangeability of light and shadow plays a symbolic role - as the dynamics of two contrary forces, the clash and connection of life and death (31-32). 

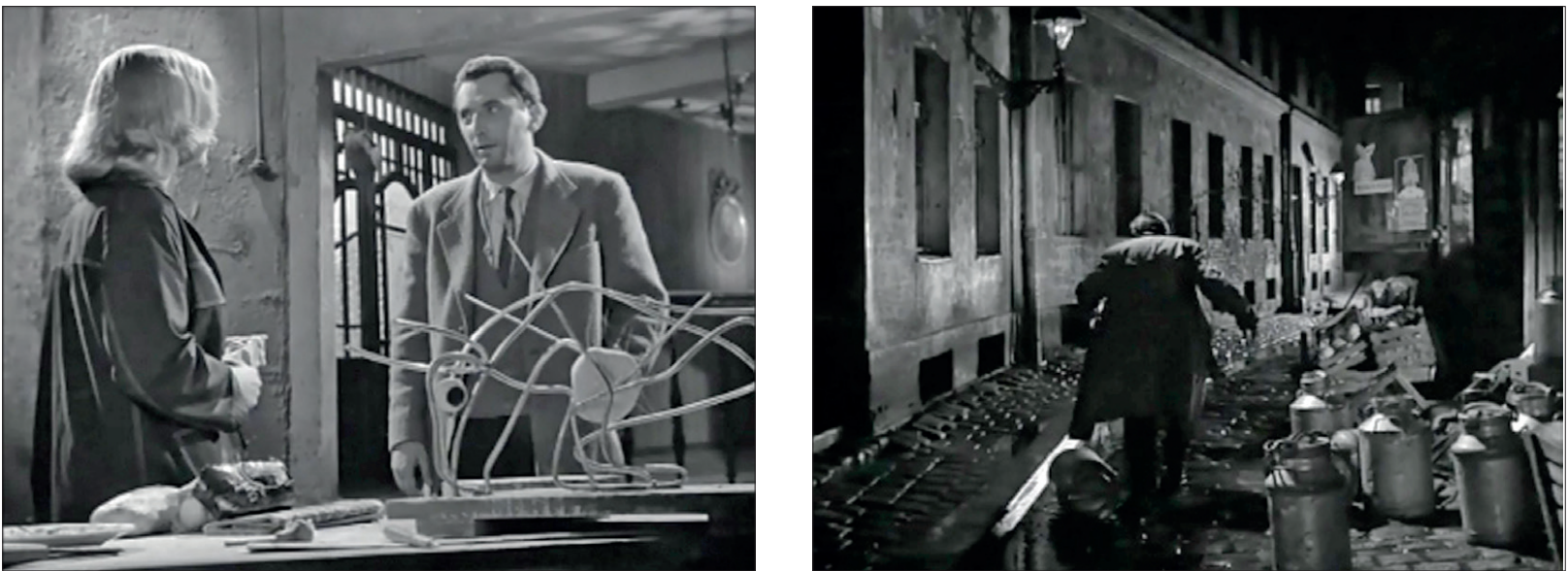

Il. 27-28. Pętla, dir. W.J. Has
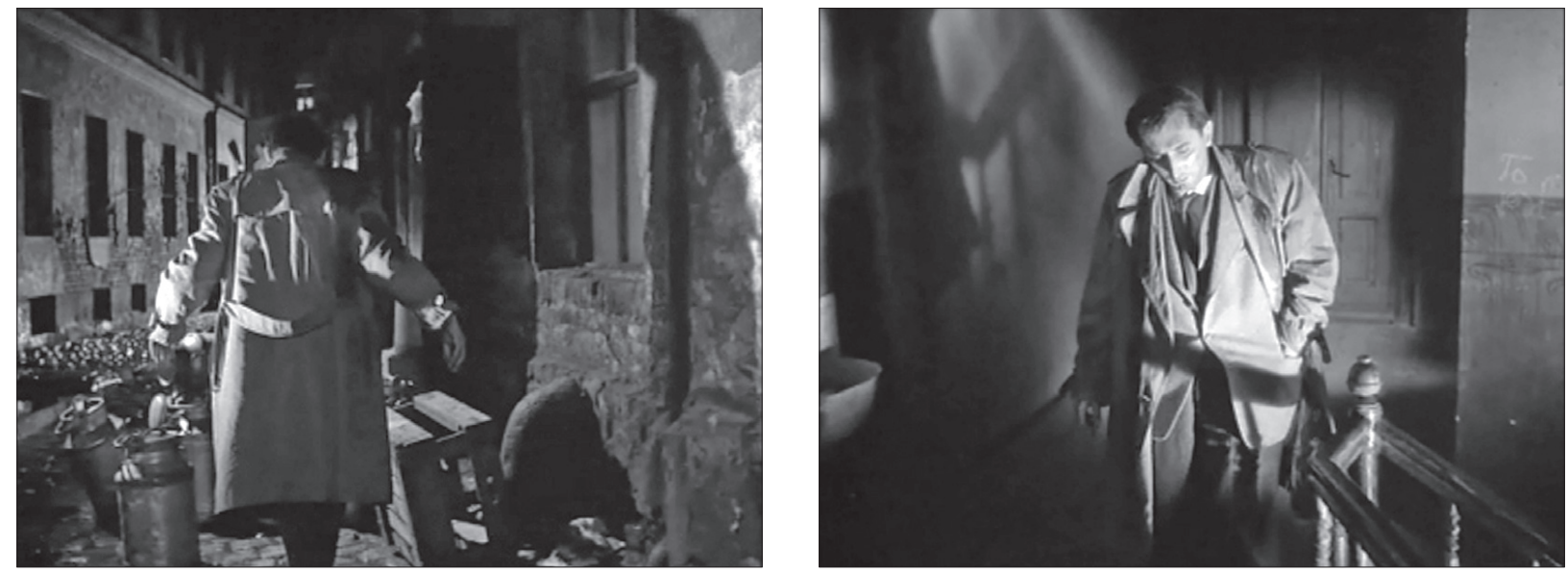

Il. 29-30. Pętla, dir. W.J. Has
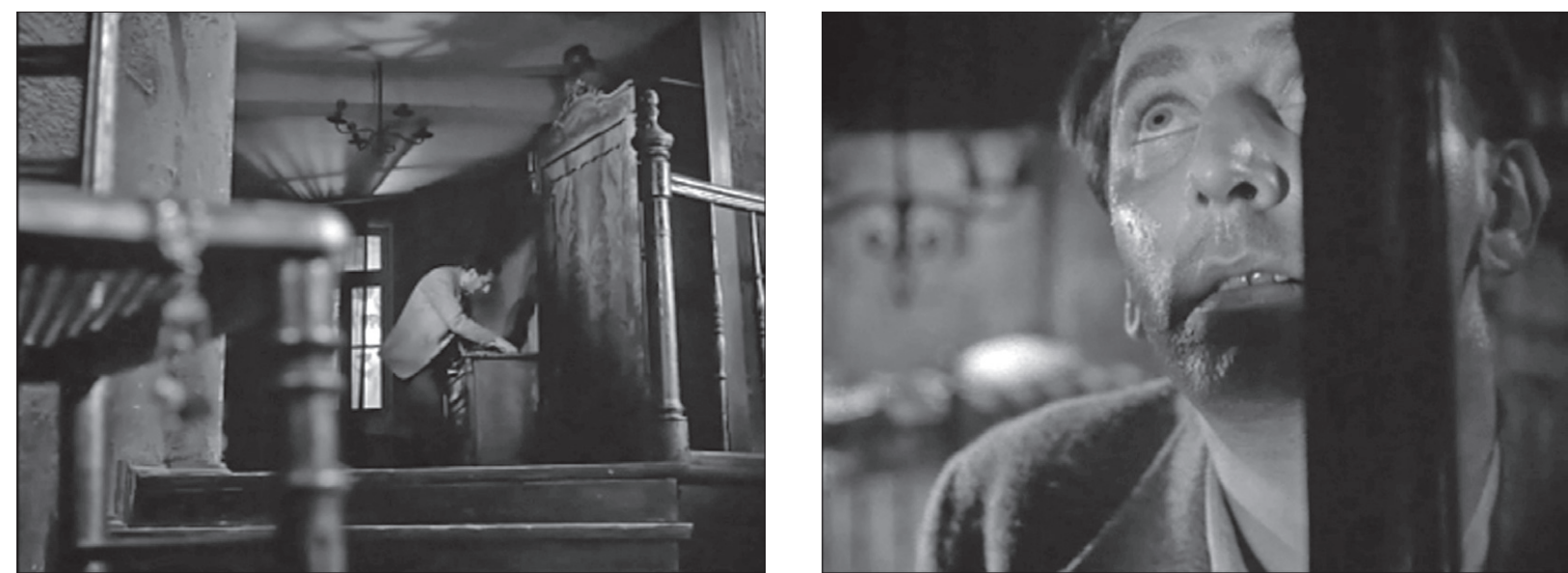

The most important property of the lighting systems created Il. 31-32. Pętla, dir. W.J. Has by Jahoda in Petla is their dynamics. Rudolf Arnheim stated that the dynamics of artistic visual images "gave them expression and meaning." [14] In a film, especially in a black and white one, such as Pętla, the

[14] R. Arnheim, Sztuka i percepcja wzrokowa. Psycho-

logia twórczego oka, przeł. J. Mach, Gdańsk 2004, p. 456. 
main factor evoking expressiveness is light. It co-forms the composition of the whole film, its spatial and time structure. The dynamics of light defines the space and time, which should be understood as the connection of successiveness and duration, so something more than only the continuum of moments.

In the case of Petla it is about a certain "state" of time and its concentration, both in passing and lasting. This is is connected with the situation and experience of the main protagonist. Kuba is afraid of memories concerning his addiction. That is why he is also afraid of the future, in which these memories might appear. His subjective experience of time resembles a loop.

The factor reinforcing the compositional dynamics of images is appropriate operating of the depth of space in a frame. The depth is basically used in two ways:

- firstly as a kind of intense visual background (il. 33-34);

- secondly, in the movement of figures appearing from the depth of the frame, from behind the protagonist's back, as if emerging from the visual and memory background as signals of the past or the future in the present time (il. 35-36). On the screen, length of time assumes
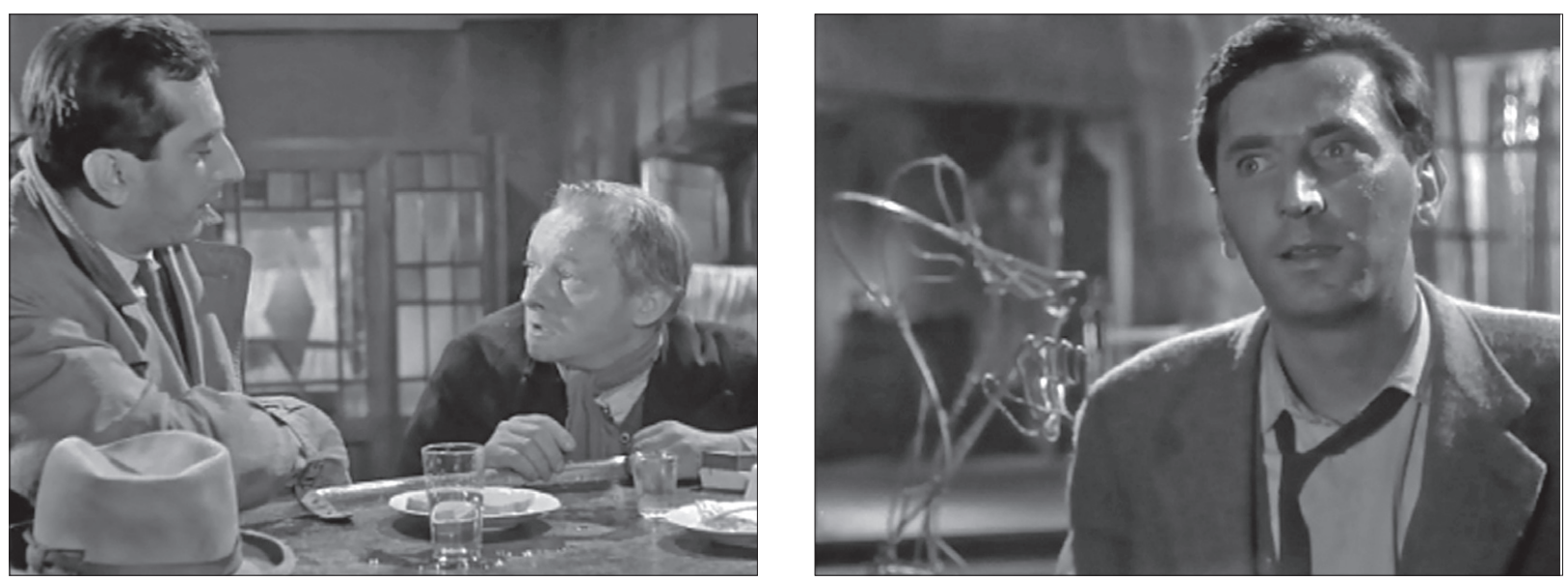

Il. 33-34. Pętla, dir. W.J. Has
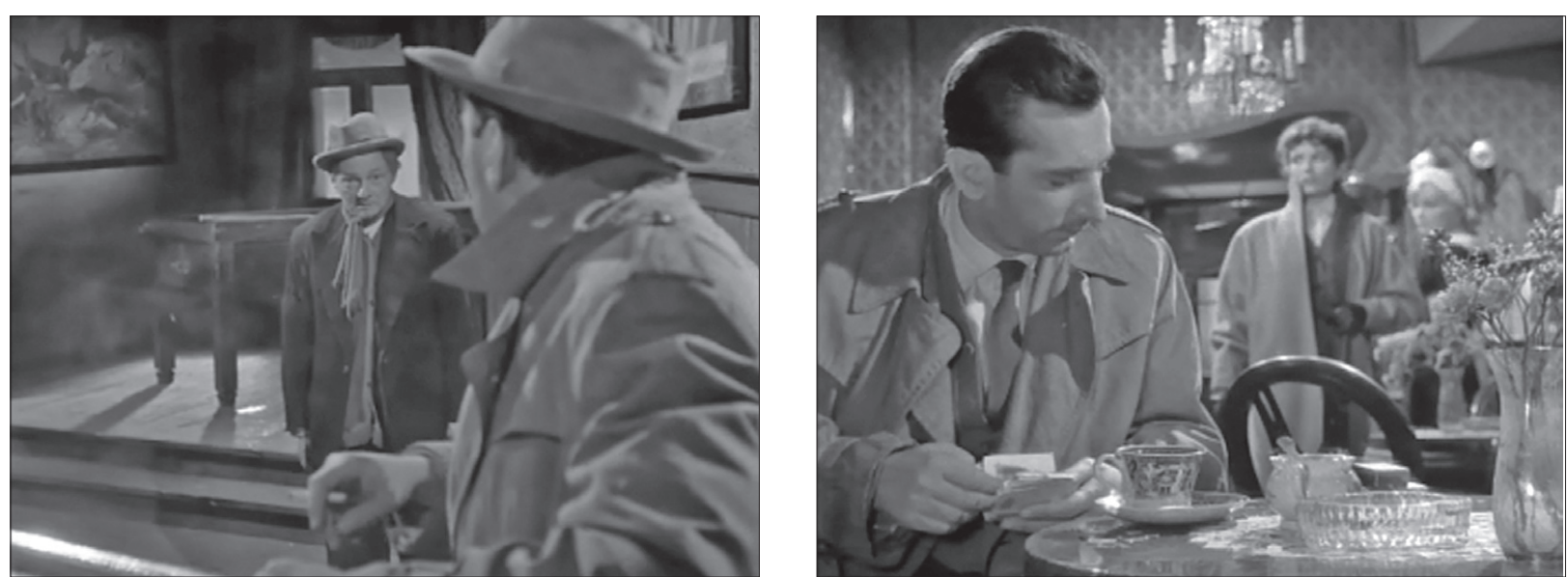

Il. 35-36. Pętla, dir. W.J. Has 
an enigmatic shape thanks to depth staging and due to the cooperation of different visual motifs in a few plans at the same time.

Let us recall that in the film the impression of depth is created by the central perspective systems. "The geometrical structure of central perspective resembles the projection that the eye would receive from one particular observation point," [15] according to Rudolf Arnheim. This is why the image determined by such a perspective resembles the point of view of the individual looking at it. Arnheim wrote that "the central perspective makes space as if similar to a stream heading for the specific destination." [16] What is more important, its projection is connected with the sense and idea of time, as it transforms "the timeless simultaneity of the traditional, not deformed space into an event in time - that is a conditioned sequence of events. The world of duration acquires the new definition: now it is the process of becoming." [17]

Such a process of becoming, evoked by subsequent systems of film space, is dealt with in Pętla. But duration is equally important in this film. That is why the filmmakers, creating the frame depth, used the method of complication and even distortion of the central perspective principles. They undertook a sort of game with the rules of perspective, modifying it in different ways.

The effect of perspective deformation is of special importance, especially in the final scenes of the film, e.g. in the scene of drunken Kuba's night wandering through the streets of town. Kuba (and the viewer with him) loses the sense of chronology of time. The depth of frames, based on the principles of central perspective, is distorted by the actor's transverse movement, direction lines running across the frame and irregular spots of shadows. That destruction of perspective or creating the impression of many perspective convergences causes a de-composition of the classic space and, at the same time the linear progress of time (il. 31-32, 37-38).

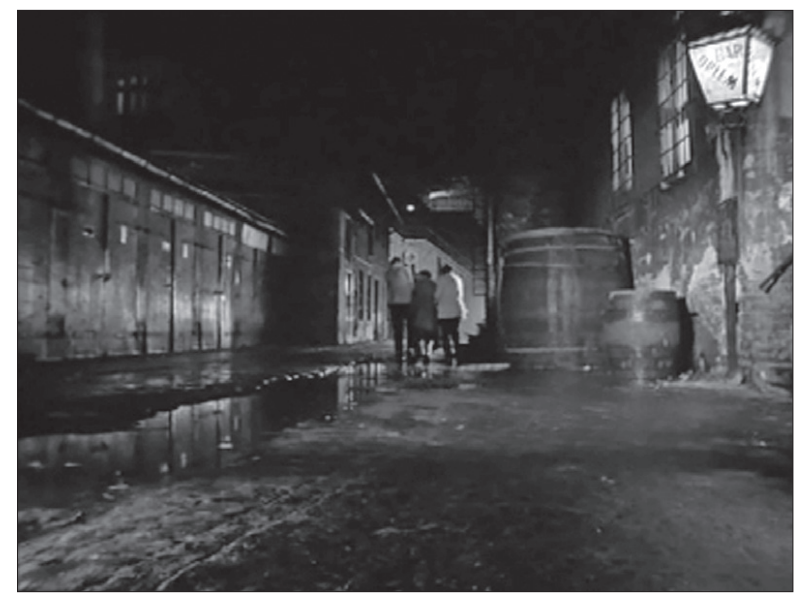

[15] Ibidem, p. 322.

[16] Ibidem, p. 335.

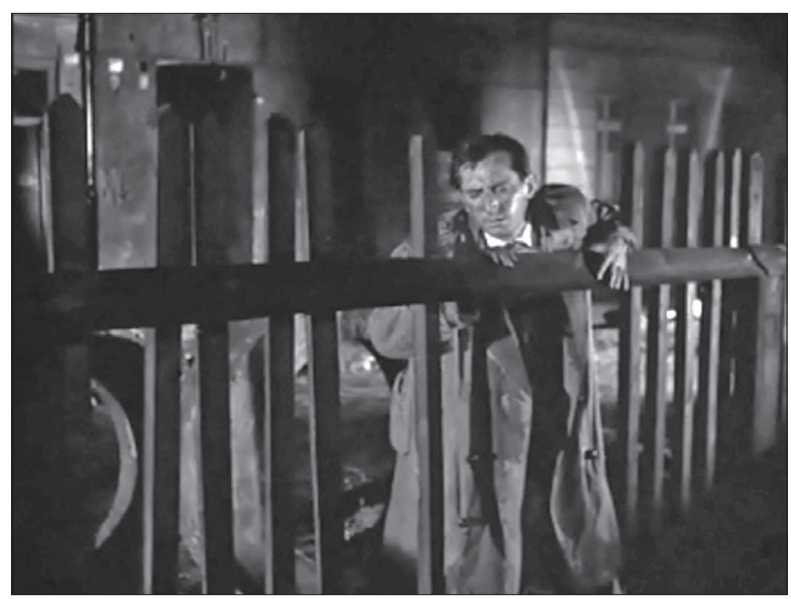

Il. 37-38. Pętla, dir. W.J. Has

[17] Ibidem. 
Jahoda used short focal length lenses: $28 \mathrm{~mm}$ and $24 \mathrm{~mm}$. Such lenses broaden the field of vision. They introduce deformations of the foreground, augmenting the objects contained in it. The image composed with the use of short focal length lenses combined with irregular scenery shapes and chiaroscuro, creates dynamic compositional systems. That is how "the unreal splendor" becomes the feature of film images in Petla, associated with the art of expressionism or surrealism.

Rudolf Arnheim stated that the dynamics of artistic images is convincing for the viewers only in an appropriately integrated film.[18] Petta is an example of such an "integrated film image". It is included in the circle of films which changed Polish cinema in the mid-1950s, forming the new type of artistic thinking about film imagery.

The visual intensity of Mieczysław Jahoda's shots in films from the mid-1950s results from the harmonious and apt application of all the cinematographer's methods: lighting, frame composition, film movement, angles of view, points of view, stress on detail and others. All these methods together form the film's space. Jahoda applied them with full awareness of their visual possibilities, but also always appropriate for the film's subjects. That was the expression of his talent and professional practice.

Arnheim R., Sztuka i percepcja wzrokowa. Psychologia twórczego oka, przeł. J. Mach, Gdańsk 2004

Eberhardt K., Wojciech Has, Warszawa 1967

Hendrykowski M., Ekran i kadr, "Przestrzenie Teorii" 2002, no. 1

Jahoda M., Styl plastyczny obrazu filmowego, a indywidualność twórcy-operatora, praca magisterska (maszynopis), Archiwum PWSFTviT, Łódź 1953

Maron M., Mieczysław Jahoda. Fenomeny światła (z opracowaniem biograficznym A.M. Leśniewskiej-Zagrodzkiej), Łódź 2019

Radzinowicz A., Scenografia filmowa, Łódź 1958

Wohl S., Operator? To filar polskiego kina. Nasza rozmowa z prof. Stanisławem Wohlem, rozmawiała B. Mruklik, "Kino" 1972, no 7

Wunenburger J.-J., Filozofia obrazów, przeł. T. Stróżyński, Gdańsk 2011

[18] Ibidem, p. 480. 